\title{
Morbidity and mortality of cervical lymphadenectomy. Analysis of 311 cases
}

\author{
Morbilidad y mortalidad de la linfadenectomía cervical. Análisis de 311 casos
}

Héctor Hernández-Vargas' ${ }^{1}$ Edgar J. Cortes-Torres' ${ }^{1}$, Alejandro González-Ojeda², Jacob E. Pérez-Landeros², Francisco J. Barrera-López ${ }^{2}$ and Clotilde Fuentes-Orozco²*

${ }^{1}$ Surgical Oncology Department; ${ }^{2}$ Biomedical Research Unit. Unidad Médica de Alta Especialidad, Hospital de Especialidades del Centro Médico Nacional de Occidente, Instituto Mexicano del Seguro Social, Guadalajara, Jalisco, Mexico

\begin{abstract}
Objective: To determine the morbidity and mortality and the risk factors associated with cervical lymphadenectomy. Method: Cross-sectional study; patients undergoing cervical lymphadenectomy were included in any of its variants, secondary to the recurrence of some neoplastic entity; from January 2011 to November 2016. Results: 311 patients were included of which $65.3 \%$ were women and $49 \pm 17.2$ years old. The most frequent diagnoses were thyroid cancer 194 (62.4\%) and recurrent laryngeal cancer 22 (7.1\%). Asymptomatic patients had 53.4\% of the patients and 119 (38.3\%) presented masses or nodules in the neck, with level III being the most affected with 276 (88.7\%) patients. Overall morbidity was $17 \%$ and mortality was $5.8 \%$. The factors related to mortality were: present symptomatology $(p=0.006)$, involvement of level I $(p=0.005)$, extensive lymph node dissection $(p=0.01)$, and vascular complications $(p=0.0001)$ and the wound $(p=0.01)$. Conclusions: Due to the lymphatic dissemination pattern of head and neck tumors, selective lymphadenectomy plays a crucial role in the treatment of these neoplasms. We have opted to perform more conservative surgeries, as long as the main oncological objectives are preserved.
\end{abstract}

Key words: Cervical lymphadenectomy. Ganglion levels. Morbidity. Mortality.

\section{Resumen}

Objetivo: Determinar la morbimortalidad y los factores de riesgo asociados a la linfadenectomía cervical. Métodos: Estudio transversal analítico en el que se incluyeron pacientes sometidos a linfadenectomía cervical en cualquiera de sus variantes, secundarios a la recurrencia de alguna enfermedad neoplásica, desde enero de 2011 hasta noviembre de 2016. Resultados: Se incluyeron 311 pacientes, de los cuales 203 (65.3\%) eran mujeres, con una edad de $49 \pm 17.2$ años. Los diagnósticos más frecuentes fueron cáncer de tiroides, en 194 (62.4\%) casos, y cáncer de laringe recurrente, en 22 (7.1\%). Cursaron asintomáticos 166 (53.4\%) pacientes, y 119 (38.3\%) presentaron masas o nódulos en el cuello, siendo el nivel III el más afectado, con 276 (88.7\%) pacientes. La morbilidad general fue del 17\% y la mortalidad fue del 5.8\%. Los factores relacionados con la mortalidad fueron la sintomatología presente $(p=0.006)$, la afectación del nivel I $(p=0.005)$, la disección ganglionar

\section{Correspondence:}

${ }^{*}$ Clotilde Fuentes Orozco

Belisario Domíngez, 1000

Col. Independencia Oblatos

Date of reception: 27-03-2018

Date of acceptance: 05-06-2018

C.P. 44349, Guadalajara, Jal., México

E-mail: clotilde.fuentes@gmail.com

0009-7411/@ 2018 Academia Mexicana de Cirugía. Published by Permanyer. This is an open access article under the terms of the CC BY-NC-ND license (http://creativecommons.org/licenses/by-nc-nd/4.0/). 
extensa $(p=0.01)$ y las complicaciones vasculares $(p=0.0001)$ y de la herida $(p=0.01)$. Conclusiones: Debido al patrón de diseminación linfática de los tumores de cabeza y cuello, la linfadenectomía selectiva desempeña un papel crucial en su tratamiento. Se ha optado por la realización de cirugías más conservadoras, siempre y cuando sean preservados los principales objetivos oncológicos.

Palabras clave: Linfadenectomía cervical. Niveles ganglionares. Morbilidad. Mortalidad.

\section{Introduction}

The presence of lymph node metastases has been estimated to indicate a $50 \%$ decrease in overall survival in patients with any nosological entity, and contralateral lymph node involvement indicates another $50 \%$ decrease. Therefore, it is important to perform cervical lymph node dissection, which contributes to the staging of certain tumors and is considered a prognostic factor ${ }^{1-3}$.

Dissection of the neck in its various forms is the standard procedure for surgical treatment of cervical lymph node metastases, since it allows extensive clearance of all lymph nodes with macroscopic growth and offers accurate histological information about the nodes at risk of developing micrometastases in a clinically negative neck, and whose purpose is local control of the disease ${ }^{4}$. Opinions vary with regard to indications for neck dissection and the type of dissection for different situations ${ }^{5,6}$.

Currently, cervical lymphadenectomy is classified in four categories: radical neck dissection, modified radical neck dissection, selective neck dissection and extended neck dissection. The transition from radical to selective neck dissection has resulted in a fewer number of complications and less morbidity, while surgical efficacy and compliance with oncological principles are preserved ${ }^{7,8}$.

Operative complications, such as vessel or nerve injury, are a cause of higher morbidity, coupled with medical complications unrelated with the procedure that may occur after cervical lymphadenectomy. Although infrequent, death can occur as a consequence of severe morbidity ${ }^{9,10}$.

The purpose of this study was to assess the complications and mortality associated with the cervical lymphadenectomy procedure, since in our institution it constitutes one of the main reasons for consultation, as well as for surgical procedures, and it is therefore necessary to detect the various risk factors associated with morbidity and mortality with the purpose to implement improvements that decrease their frequency.

\section{Method}

An analytical cross-sectional study was carried out. The surgical oncology department database was reviewed and all patients who had undergone cervical lymphadenectomy in any of its variants as a surgical procedure, due to lymph node recurrence of any neoplasm during the period from January 1 , 2011 to November 30, 2016 were included. Patients who had unresectability criteria, such as spine or spinal cord compromise, and those with serious comorbidity preventing said procedure were excluded.

Variables such as age, gender, presentation symptoms, primary neoplasm and type of performed surgery (radical, modified, selective, supraomohyoiod, lateral, posterolateral, central and posterior dissection) were collected and compared with the histopathology result, postoperative complications associated with procedure (of the wound itself, vascular, nervous and chylous fistula) and postsurgical mortality.

\section{Statistical analysis}

The variables were captured on an electronic database and were subjected to statistical analysis using the SPSS program (version 21.0; IBM Corp., Armonk, NY, USA). Raw numbers and percentages were obtained for qualitative variables, and means with their standard deviation for quantitative variables. The inferential phase was carried out through a univariate analysis with the chi-square test or Fisher's exact test for qualitative variables and odds ratios (OR) and 95\% confidence intervals (Cl) calculation. Any $p$-value $<0.05$ was considered statistically significant.

\section{Ethical considerations}

Ethical aspects in this study are based on the Regulations of the General Statute Law in Matters of Health Research and on the Declaration of Helsinki and its 
amendments, as well as on national and international codes in force for good research practice. The study was approved by the Local Research and Ethics in Health Research Committee with registration number R-2016-1301-117. The study was carried out with the institution's own resources, and thus it is declared that there is no conflict of interest.

\section{Results}

Three-hundred and eleven patients were included, $108(34.7 \%)$ of the male gender and $203(65.3 \%)$ of the female gender. Age was $49 \pm 17.2$ years. The most common diagnosis was thyroid cancer in 194 patients $(62.4 \%)$, followed by recurrent laryngeal cancer in 22 patients $(7.1 \%)$, and cervical metastases of unknown primary in 16 patients $(5.1 \%)$. With regard to symptoms, 166 patients $(53.4 \%)$ were asymptomatic and $119(38.3 \%)$ referred the presence of masses or nodules in the neck; out of them, $26(8.4 \%)$ had symptoms such as dysphagia or dysphonia.

As for surgical dissection, 108 (34.7\%) underwent lateral lymph node dissection, 78 (25\%), type 3 modified radical dissection and 48 (15.4\%). supraomohyoid dissection (Table 1). Of total resected lymph nodes, $47(15.1 \%)$ were benign and $264(84.9 \%)$ were positive for malignancy.

The resected lymph node levels corresponded to level III in 185 patients (59.4\%); in 177 (56.9\%), to level II; in $100(32.1 \%)$, to level IV; in $66(21.2 \%)$, to level I; in $45(14.4 \%)$, to level $\mathrm{VI}$; in $28(9 \%)$, to level $\mathrm{V}$; and in $16(5.1 \%)$, to level VII.

\section{Vascular complications}

Risk factors associated with vascular complications were analyzed, out of which high blood pressure (OR: 2.7; $95 \% \mathrm{Cl}: 1.1-6.5 ; p=0.02$ ), clinical symptoms (OR: 2.8; $95 \% \mathrm{Cl}: 1.1-7.1 ; \mathrm{p}=0.01)$, type III radical dissection (OR: 3; $95 \% \mathrm{Cl}: 1.2-7.1 ; \mathrm{p}=0.01$ ) and supraomohyoid dissection (OR: $0.9 ; 95 \% \mathrm{Cl} 0.8-0.9 ; \mathrm{p}=0.01$ ) were found to be, as seen in table 2 .

\section{Nerve complications}

Major hypoglossal nerve lesions were found in 9 patients $(2.8 \%)$ and recurrent laryngeal nerve lesion was found in $1(0.3 \%)$, which were associated with level I (OR: 19.1; 95\% Cl: 4.0-91.2; $\mathrm{p}=0.00$ ) and level II resection (OR: 1; 95\% Cl: 1.0-1.1; $p=0.002$ ).
Table 1. Demographic and clinical characteristics of the study population

\begin{tabular}{|c|c|}
\hline Variable & n (\%) \\
\hline \multicolumn{2}{|l|}{ Gender } \\
\hline Males & $108(34.7)$ \\
\hline Females & $203(65.3)$ \\
\hline Age (years) & $49 \pm 17.2$ \\
\hline Hospital stay (days) & $4.2 \pm 4$ \\
\hline \multicolumn{2}{|l|}{ Diagnosis } \\
\hline Thyroid cancer & $194(62.4)$ \\
\hline Larynx cancer & $22(7.1)$ \\
\hline Cervical metastasis of unknown primary tumor & $16(5.1)$ \\
\hline Parotid cancer & $11(3.5)$ \\
\hline Melanoma & $11(3.5)$ \\
\hline Tongue cancer & $9(2.9)$ \\
\hline Others & $48(15.6)$ \\
\hline \multicolumn{2}{|l|}{ Clinical presentation } \\
\hline Asymptomatic & $166(53.4)$ \\
\hline Masses or nodules & $119(38.3)$ \\
\hline Others & $26(8.4)$ \\
\hline \multicolumn{2}{|l|}{ Morbidity } \\
\hline Vascular complications & $23(7.4)$ \\
\hline Nerve complications & $11(3.5)$ \\
\hline Wound complications & $19(6.1)$ \\
\hline Mortality & $18(5.8)$ \\
\hline \multicolumn{2}{|l|}{ Comorbidity } \\
\hline Diabetes mellitus (DM) & $21(6.8)$ \\
\hline High blood pressure (HBP) & $37(11.9)$ \\
\hline $\mathrm{DM}$ and $\mathrm{HBP}$ & $36(11.6)$ \\
\hline Other & $12(3.8)$ \\
\hline \multicolumn{2}{|l|}{ Type of surgery } \\
\hline Type I radical dissection & $3(1)$ \\
\hline Type III modified radical dissection & $78(25)$ \\
\hline Supraomohyoid dissection & $48(15.4)$ \\
\hline Lateral dissection & $108(34.7)$ \\
\hline Posterolateral dissection & $29(9.3)$ \\
\hline Anterior dissection & $25(8)$ \\
\hline Lateral and anterior dissection & $19(6.1)$ \\
\hline Posterior dissection & $1(0.3)$ \\
\hline \multicolumn{2}{|l|}{ Histopathological result } \\
\hline Positive & $264(84.9)$ \\
\hline Negative & $47(15.1)$ \\
\hline
\end{tabular}

\section{Wound complications}

Surgical wound complications were infection in 3 patients $(0.9 \%)$, surgical wound dehiscence in 8 $(2.5 \%)$ and seroma in $2(0.6 \%)$. A higher risk was observed in male patients (OR: $0.2 ; 95 \% \mathrm{Cl}: 0.1-0.7$; $\mathrm{p}=0.009$ ), with diabetes mellitus (OR: $2.8 ; 95 \% \mathrm{Cl}$ : $1.0-7.5 ; p=0.04$ ) and with lateral dissection (OR: 0.3; $95 \% \mathrm{Cl} 0.09-1.1 ; \mathrm{p}=0.05)$. 
Table 2. Factors associated with morbidity (complications)

\begin{tabular}{|c|c|c|c|c|c|c|c|c|}
\hline \multirow[t]{2}{*}{ Variable } & \multicolumn{2}{|c|}{ Vascular } & \multicolumn{2}{|c|}{ Nerve } & \multicolumn{2}{|c|}{ Wound } & \multicolumn{2}{|c|}{ Chylous fistula } \\
\hline & Yes/No & $p^{*}$ & Yes/No & $p^{*}$ & Yes/No & $p^{*}$ & Yes/No & $p^{*}$ \\
\hline \multicolumn{9}{|l|}{ Gender } \\
\hline Males & $11 / 108$ & 0.12 & $7 / 108$ & 0.04 & $12 / 108$ & 0.009 & $8 / 108$ & 0.02 \\
\hline Females & $12 / 203$ & & $4 / 203$ & & $7 / 203$ & & $4 / 203$ & \\
\hline \multicolumn{9}{|l|}{ Comorbidity } \\
\hline Diabetes mellitus & $6 / 57$ & 0.22 & $4 / 57$ & 0.12 & $7 / 57$ & 0.04 & $2 / 57$ & 0.61 \\
\hline High blood pressure & $10 / 73$ & 0.02 & $1 / 73$ & 0.22 & $7 / 73$ & 0.12 & $3 / 73$ & 0.56 \\
\hline \multicolumn{9}{|l|}{ Clinical level } \\
\hline I & $13 / 129$ & 0.09 & $10 / 129$ & 0.001 & $12 / 129$ & 0.04 & $7 / 129$ & 0.18 \\
\hline II & 22/272 & 0.18 & $11 / 272$ & 0.22 & $18 / 272$ & 0.28 & $11 / 272$ & 0.54 \\
\hline III & 22/276 & 0.24 & $11 / 276$ & 0.26 & $19 / 276$ & 0.09 & $11 / 276$ & 0.60 \\
\hline IV & $9 / 217$ & 0.12 & $3 / 217$ & 0.004 & $15 / 217$ & 0.26 & $11 / 217$ & 0.07 \\
\hline V & $12 / 87$ & 0.009 & $3 / 87$ & 0.63 & $8 / 87$ & 0.12 & $7 / 87$ & 0.02 \\
\hline VI & $3 / 58$ & 0.34 & $0 / 58$ & 0.09 & $2 / 58$ & 0.27 & $2 / 58$ & 0.60 \\
\hline VII & $3 / 46$ & 0.54 & $0 / 46$ & 0.16 & $1 / 46$ & 0.19 & $2 / 46$ & 0.55 \\
\hline \multicolumn{9}{|l|}{ Surgical level } \\
\hline I & $3 / 66$ & 0.23 & $9 / 66$ & 0.00 & $6 / 66$ & 0.19 & $1 / 66$ & 0.23 \\
\hline$\|$ & $14 / 177$ & 0.43 & 11/177 & 0.002 & $14 / 177$ & 0.09 & $7 / 177$ & 0.58 \\
\hline III & 19/185 & 0.01 & 6/185 & 0.48 & 13/185 & 0.28 & 10/185 & 0.07 \\
\hline IV & $9 / 100$ & 0.29 & $1 / 100$ & 0.08 & $5 / 100$ & 0.38 & $6 / 100$ & 0.015 \\
\hline V & $3 / 28$ & 0.34 & $0 / 28$ & 0.34 & $2 / 28$ & 0.52 & $2 / 28$ & 0.29 \\
\hline $\mathrm{VI}$ & $2 / 45$ & 0.32 & $0 / 45$ & 0.17 & $2 / 45$ & 0.46 & $0 / 45$ & 0.14 \\
\hline VII & $1 / 16$ & 0.66 & $0 / 16$ & 0.55 & $0 / 16$ & 0.35 & $0 / 16$ & 0.52 \\
\hline Symptoms & $16 / 145$ & 0.019 & $8 / 145$ & 0.07 & $14 / 145$ & 0.01 & $10 / 145$ & 0.009 \\
\hline \multicolumn{9}{|l|}{ Type of surgery } \\
\hline Type III radical dissection & $11 / 78$ & 0.01 & $4 / 78$ & 0.28 & $8 / 78$ & 0.07 & $6 / 78$ & 0.05 \\
\hline Supraomohyoid dissection & $0 / 48$ & 0.01 & $7 / 48$ & 0.00 & $3 / 48$ & 0.58 & $0 / 48$ & 0.12 \\
\hline Lateral dissection & $8 / 108$ & 0.58 & 0/108 & 0.008 & $3 / 108$ & 0.05 & $4 / 108$ & 0.59 \\
\hline Posterolateral dissection & $0 / 29$ & 0.09 & $0 / 29$ & 0.33 & 2/29 & 0.54 & $0 / 29$ & 0.30 \\
\hline Anterior dissection & $0 / 25$ & 0.13 & $0 / 25$ & 0.39 & $0 / 25$ & 0.19 & $0 / 25$ & 0.35 \\
\hline Lateral and anterior dissection & $3 / 19$ & 0.15 & 0/19 & 0.49 & 2/19 & 0.32 & $1 / 19$ & 0.53 \\
\hline
\end{tabular}

*By chi-square test or Fisher's exact test.

\section{Chylous fistula}

In the $12(3.85 \%)$ patients who developed chylous fistula, male gender (OR: $0.2 ; 95 \% \mathrm{Cl}: 0.7-0.8$; $\mathrm{p}=0.02$ ) and type III radical dissection (OR: 3.1; 95\% Cl: $0.9-10 ; p=0.05$ ) were found to be risk factors.

\section{Mortality}

Eighteen patients died (death rate of $5.8 \%$ ), out of which eight died due to severe postoperative hemorrhage, five due to sepsis, two due to complications associated with a chylous fistula and the rest due to complications unrelated to the procedure. The factors that were associated with mortality were presence of clinical symptoms (OR: 4.32; 95\% Cl: 1.3-13.4; $p=0.006$ ), level I metastases (OR: $4.41 ; 95 \% \mathrm{Cl}$ :
1.5-10.9; $p=0.005)$, type 3 modified radical dissection (OR: $3.2 ;$ IC 95\%: 1.2-8.5; $p=0.01$ ) and vascular (OR: $11 ; 95 \% \mathrm{Cl}: 3.7-32.2 ; p=0.0001)$ and wound complications (OR: $5.29 ; 95 \% \mathrm{Cl}: 1.5-18.0 ; p=0.01$ ), as observed in table 3 .

\section{Discussion}

Cervical lymphadenectomy in patients with head and neck tumors continues to be considered the first line of treatment for lymph node metastases of tumors of this region, as well as one of the main tools for staging, which is considered the most important prognosis factor of aerodigestive tract neoplasms malignancy ${ }^{1,2}$.

As it could be observed in our study, there is a large number of tumors that cause metastases in cervical lymph nodes, among which the vast majority are found 
Table 3. Univariate analysis of factors associated with mortality in the study population

\begin{tabular}{|c|c|c|c|}
\hline Variable & $n=18$ & $\mathbf{p}^{*}$ & OR $(95 \% \mathrm{Cl})$ \\
\hline \multicolumn{4}{|l|}{ Gender } \\
\hline Males & $9 / 108$ & 0.12 & $0.5(0.1-1.3)$ \\
\hline Females & 9/203 & & \\
\hline \multicolumn{4}{|l|}{ Diagnosis } \\
\hline Thyroid cancer & $9 / 194$ & 0.19 & $0.58(0.2-1.5)$ \\
\hline Melanoma & $2 / 11$ & 0.12 & $3.94(0.7-19.7)$ \\
\hline Laryngeal cancer & $2 / 22$ & 0.36 & $1.7(0.3-7.9)$ \\
\hline Squamous cell cancer & $1 / 5$ & 0.25 & $4.2(0.4-40.1)$ \\
\hline \multicolumn{4}{|l|}{ Type of surgery } \\
\hline Type III radical dissection & $9 / 78$ & 0.01 & $3.24(1.2-8.5)$ \\
\hline Supraomohyoid dissection & $3 / 48$ & 0.54 & $1.10(0.3-3.9)$ \\
\hline Lateral dissection & $4 / 108$ & 0.18 & $0.51(0.16-1.6)$ \\
\hline Anterior dissection & $1 / 25$ & 0.56 & $0.65(0.08-5.1)$ \\
\hline Posterolateral dissection & $0 / 29$ & 0.16 & $0.93(0.9-0.9)$ \\
\hline Lateral and anterior dissection & $1 / 19$ & 0.69 & $0.89(0.1-7.1)$ \\
\hline \multicolumn{4}{|l|}{ Complications } \\
\hline Vascular & $7 / 23$ & 0.0001 & $11(3.7-32.2)$ \\
\hline Nerve & $1 / 11$ & 0.48 & $1.66(0.2-13.7)$ \\
\hline Wound & $4 / 19$ & 0.01 & $5.29(1.5-18.0)$ \\
\hline Chylous fistula & $2 / 12$ & 0.14 & $3.53(0.7-17.5)$ \\
\hline Pathology result & 17 & 0.21 & $3.16(0.4-24.3)$ \\
\hline Symptoms present & 14 & 0.006 & $4.32(1.3-13.4)$ \\
\hline \multicolumn{4}{|l|}{ Lymph node level } \\
\hline I & 9 & 0.005 & $4.41(1.5-10.9)$ \\
\hline$\|$ & 12 & 0.27 & $1.52(0.5 .4 .2)$ \\
\hline III & 14 & 0.81 & $2.94(0.8-7.7)$ \\
\hline IV & 6 & 0.54 & $1.05(0.3-2.9)$ \\
\hline V & 3 & 0.21 & $2.14(0.5-7.9)$ \\
\hline VI & 2 & 0.50 & $0.72(0.1-3.2)$ \\
\hline VII & 0 & 0.61 & $0.94(0.9-0.9)$ \\
\hline
\end{tabular}

*By chi-square test or Fisher's exact test.

Cl: confidence interval; OR: odds ratio.

to correspond to thyroid-origin tumors, which account for $62 \%$ in our population, while in world literature percentages of up to $72 \%$ can be found, which are associated with low lethality but high incidence ${ }^{3}$. If we consider aerodigestive tract tumors in general, we find an incidence of cervical metastases of around $16 \%$, which is higher when compared to the literature, which reports $12 \%$; however, in contrast with the results obtained in studies carried out in other countries, we observe that larynx neoplasms in our study rank second ${ }^{6,10,11}$.

According to the classification proposed since 1987 by the American Head and Neck Society (AHNS) and the American Academy of Otolaryngology-Head and Neck Surgery (AAO-HNS), it could be appreciated that the most affected levels are II, III and IV, which, if the lymphatic drainage of each tumor is analyzed, corresponds to the natural evolution of its dissemination ${ }^{7,12,13}$, since they have a predictable and sequential pattern, as observed in thyroid, tongue, gum, larynx and parotid tumors, which have drainage towards these levels and therefore there is correlation with the resected lymph node levels, with a lower proportion of levels $\mathrm{V}$, $\mathrm{VI}$ and VII. When analyzing asymptomatic patients in comparison with those who have cervical nodules or masses, we see that these are a recurrence prognostic parameter, since all those who have symptoms are positive for malignancy in the histopathological examination, with this difference being statistically significant, which is consistent with Sugitani et al. findings ${ }^{13}$, who found that $20.6 \%$ of patients with palpable lymph nodes developed nodal recurrence, this way considering those presenting with lymph nodes of $3 \mathrm{~cm}$ or more as high-risk patients.

According to lymphadenectomies surgical evolution, conservative management is increasingly being preferred, since previous studies have shown that the resection of lymph node-unrelated structures, such as the spinal nerve, muscles or blood vessels, offers no advantage in terms of overall survival or disease-free period $^{14-16}$. We agree with the world literature by performing more conservative surgeries, with resection of lymph node levels by groups depending on the affected levels and the possibility of metastasis contiguously, and this is why levels II, III and IV lateral dissection continues to be the most performed surgery, followed by type 3 modified radical dissection, which includes lymph node levels I to $\mathrm{V}$, preserving lymph node-unrelated structures, or supraomohyoid dissection for higher levels. The extent of lymphadenectomy directly influences morbidity, mainly with vascular conditions, when performing extensive dissections such as modified radical dissection

The presence of nodules at jugular levels and their resection significantly affect the increase of hematomas and incidental perforations in the jugular vein, which in correlation with the extent of lymphadenectomy in a radical dissection can occur in up to $4 \%$ according to the literature ${ }^{6,11}$ ( $5 \%$ in our study).

The incidence of surgical complications is variable, dependent on each surgeon and each hospital, in addition to being correlated with tumor ${ }^{17}$ histological type. In our study, we found a complication rate of $17 \%$, which include nerve and vascular complications and those inherent to the wound, in contrast with observations reported by Dedivitis et al. ${ }^{18}$, who found a frequency of up to $28 \%$. The most common complications in our population were vascular, unlike the previously mentioned study ${ }^{18}$, where nerve complications 
(damage to the mandibular nerve marginal branch, accessory nerve) were the most common.

As for nerve complications, according to international literature, an incidence of $1-2 \%$ has been reported ${ }^{19}$; however, there is no long-term information available of the possible benefits of rehabilitation, in contrast with evidences $^{11,12}$ that reveal an improvement in a large percentage of patients, with only $3 \%$ that will remain with a permanent sensory or motor deficit. In our study we did not find spinal nerve injuries, while we did find them in the major hypoglossal nerve or the marginal facial branch (3.5\%), which resulted in homolateral lingual weakness, deviation of the tongue to the affected side and, to a lesser extent, difficulty with speech and swallowing (only one patient had these deficits).

Wound-inherent complications had a frequency of $6.1 \%$, which is lower than that observed in the series of Pellini et al. ${ }^{20}$, where they report up to $20 \%$. In a larger proportion, dehiscence of the wound and infection were observed, and as associated factors, the presence of diabetes mellitus and having received external radiotherapy were found, which are directly proportional to the mortality rates observed in this study. Therefore, management with prophylactic antimicrobials, as well as gentle management of irradiated tissues, as reported in the literature, reduce the incidence of wound infections.

According to reports in international literature $8,10,17$, the presence of chylous fistula is observed in 1-2.5\% of cases. In our study, we observed them in $1.9 \%$ and were resolved with medical management; one patient required surgery, and direct impact on mortality was not demonstrated.

Cervical lymphadenectomy is the first treatment option for patients with cervical neoplasms of the head and neck lymph node metastase ${ }^{20}$, and also with distant neoplasms that give rise to metastases to the neck, such as lung, breast, endometrium tumors and sarcomas. Its management is considered safe, with a percentage of complications lower than $7 \%$. We are still observing patients with tumors with an unfavorable prognosis, of large dimensions, which ulcerate and infiltrate the skin, with these being the tumors with the highest rate of complications, such as wound dehiscence and vascular conditions; the decrease in their incidence can only be achieved with careful surgical techniques and clear therapeutical indications ${ }^{21,22}$.

\section{Conclusions}

Cervical lymphadenectomy is the ideal treatment for regional control in patients with lymph node metastases, avoiding unnecessary resection of nonlymphatic structures. An overall morbidity of $17 \%$ was observed, which is similar to that recorded in other specialized centres. Performing more conservative surgeries has been chosen, as long as regional control of disease is achieved, given the direct relationship between lymph node metastases and the increase in both neoplastic persistence and recurrence. Since cervical lymphadenectomy is an element to stage neoplasms originating in the head and neck, and in those that are metastasis of distant neoplasms, the importance of its performance stands out, since the benefit of lymph node resection outweighs the low rate of complications expected from said surgery.

\section{References}

1. Cadena E, Sanabria A. Disección ganglionar de cuello: conceptos actuales. Rev Colomb Cancerol. 2011;15:31-40.

2. Pellini R, Mercante G, Marchese C, Terenzi V, Sperduti I, Manciocco V, et al. Predictive factors for postoperative wound complications after neck dissection. Spriano Acta Otorhinolaryngologica Italica. 2013;33:16-22.

3. Chan JY. Efficacy of neck dissection in the management of isolated nodal recurrence after head and neck cancer treatment. Curr Oncol Rep. 2013;15:142-5

4. Alfio Ferlito K, Robbins T, Silver CE, Hasegawa Y, Rinaldo A. Classification of neck dissections: an evolving system. Auris Nasus Larynx. 2009;36:127-34

5. Chummun S, McLean NR, Ragbir M. Surgical education: neck dissection. Br J Plast Surg. 2004;57:610-23.

6. Prim MP, De Diego JI, Verdaguer JM, Sastre N, Rabanl I. Neurologic complications following neck dissection. Eur Arch Otorhinolaryngol. 2006;263:473-6.

7. Ducic Y, Young L, Mclntyre J. Neckissection: Past and present. Minerva Chir. 2010;65(1):45-58.

8. Smoke A, Delegge MH. Chyle leaks: consensus on management? Nutr Clin Pract. 2008:23:529-32.

9. Pellini R, Mercante G, Marchese C, Terenzi V, Sperduti I, Manciocco V, et al. Predictive factors for postoperative wound complications after neck dissection. Acta Otorhinolaryngol. 2013;33:16-22.

10. Ferlito A, Rinaldo A, Robbins KT, Silver CE. Neck dissection: past, present and future? J Laryngol Otol. 2006;120:87-92.

11. Ferlito A, Rinado A, Silver CE, Shah JP, Suárez C, Medina JE, et al. Neck dissection: then and now. Auris Nasus Larynx. 2006;33(4):365-74.

12. Ferlito A, Robbins KT, Shah JP, Medina JE, Silver CE, Al-Tamimi S, et al. Proposal for a rational classification of neck dissections. Head Neck. 2011;33:445-50.

13. Sugitani I, Fujimoto Y, Yamada K, Yamamoto N. Prospective outcomes of selective lymph node dissection for papillary thyroid carcinoma based on preoperative ultrasonography. World J Surg. 2008;32:2494-502.

14. Nobuyuki W, Quan-Yang D, Kiminori S, Hiroyuki I, Kaori K, Takashi M, et al. Lymph node metastasis from 259 papillary thyroid microcarcinomas. Frequency, pattern of occurrence and recurrence, and optimal strategy for neck dissection. Ann Surg. 2003;237:399-407.

15. Morestin $\mathrm{H}$. The evidence of cervical nodes in cancers of the mouth and pharynx. J Chir. 1993:10:657-93.

16. Rigual NR, Wiseman SM. Neck dissection: current concepts and future directions. Surg Oncol Clin Am. 2004;13:151-66.

17. Giugliano G, Proh M, Gibelli B, Grosso E, Tagliabue M, De Fiori E, et al. Central neck dissection in differentiated thyroid cancer: technical notes. Acta Otorhinolaryngol Ital. 2014;34:9-14

18. Dedivitis RA, Guimarães AV, Pfuetzenreiter EG Jr, Castro MA. Neck dissection complications. Braz J Otorhinolaryngol. 2011;77:65-9.

19. Hughes DT, Doherty GM. Central neck dissection for papillary thyroid cancer. Cancer Control. 2011;18:83-8.

20. Pellini R, Mercante G, Marchese C, Terenzi V, Sperduti I, Manciocco V, et al. Predictive factors for postoperative wound complications after neck dissection. Acta Otorhinolaryngol Ital. 2013;33:16-22.

21. Shoppy WD, Holsinger FC. Management of the neck in thyroid cancer. Otolaryngol Clin N Am. 2014;47:545-56.

22. Kerawala CJ. Complications of head and neck cancer surgery. Prevention and management. Oral Oncology. 2010;46:433-5. 